Для йитирования: Ершов М.Ф., Киселев А.Г. Хрестоматия по истории российского казачества для средней школы: методологические основания и принципы составления // Вестник угроведения. 2018. Т. 8. № 1. С. 173-185.

\title{
Chrestomathy on the history of the Russian Cossacks for secondary school: methodological foundations and principles of compilation
}

\author{
M.F. Ershov \\ Ob-Ugric Institute of Applied Researches and Development, \\ Khanty-Mansiysk, Russian Federation, \\ mfershov@mail.ru \\ A.G. Kiselev \\ Ob-Ugric Institute of Applied Researches and Development», \\ Khanty-Mansiysk, Russian Federation, \\ kiselev1954@mail.ru
}

\begin{abstract}
Introduction: modern educational standards direct a school on the so-called active approach to education requiring the proper training and methodological support. Especially relevant this task is for disciplines newly introduced into the educational program, including before the special course on the history of the Russian Cossacks for the cadet classes with the Cossack component in the educational program.

Objective: to define the basic principles of creating this type of textbook as a chrestomathy with materials for the organization of independent study of students.

Review of literature of methodological and historical nature predetermined the reference to the new scientific direction - methodology of history (A. Petrov) as a synthesis of the achievements of historical science and the previous methodological developments in teaching of history. The authors came to the conclusion that it is necessary to use in the methodology not only the provisions of didactics, but also data of historical science to identify the contents of a chrestomathy and methods of its learning.
\end{abstract}

Research materials: methodological and historical literature selected by the authors. As a universal approach to its analysis and synthesis the principles of social, cultural, mental, intellectual history were used; they allowed seeing the "human face" of history, to achieve both educational results and educational effect.

Results and novelty of the research: the results of the study are divided into three groups: an assessment of the status and prospects of evolution of the Russian Cossacks, situational moments in teaching of history in a modern school, and, finally, the principles of compiling of collections of educational materials (chrestomathies) on the history of the Cossacks.

The scope of the discussion included the problem of the relation between form and content of a teacher's work, tutorial work, the role of the teacher in the educational process, and the so-called "methodology of history". The authors offered the approaches which were used by them in preparing of the original version of "The chrestomathy on history of the Russian Cossacks" as significant moments.

Key words: Federal state educational standards, activity-based and competency-based approaches to learning, humanities knowledge and information, the history of the Russian Cossacks, the role of the teacher in the educational process, chrestomathy on the history of the Cossacks.

Acknowledgements: the authors thank for the interest and good advices:

G.S. Zaitsev, Adviser of the Supreme Ataman of the Union of Cossacks of Russia, Deputy Ataman of Siberian Cossack army, Colonel of the Union of Cossacks of Russia, Honorary Ataman of the Cossacks of Yamalo-Nenets Autonomous - Okrug, Candidate of Historical Sciences;

G.V. Klushin, Ataman of Ob-Irtysh divisional Cossack Society of the Siberian Army Cossack Society;

A.A. Stankin, Captain, Chief of staff, First Deputy Ataman of the Cossack society "Stanitsa Yugorskaya", Candidate of Economic Sciences;

D.V. Filipchuk, Leading Expert of the Okrug House of Folk Arts of KhMAO - Yugra;

A.M. Losunov, Omsk historian and ethnographer.

For citation: Ershov M.F., Kiselev A.G. Chrestomathy on the history of the Russian Cossacks for secondary school: methodological foundations and principles of compilation // Vestnik ugrovedenia = Bulletin of Ugric studies. 2018; 8(1): 173-185. 


\section{Введение}

Современная средняя школа переживает непростые времена перехода на новые федеральные образовательные стандарты, ориентированные на развитие личности, прежде всего, через освоение универсальных учебных действий и, выработку определённых метапредметных компетенций. Одной из современных реалий является появление новых учебных дисциплин в формате дополнительных специальных курсов. К числу последних относится история российского казачества, внимание к которой во многом связано с современными социокультурными процессами в казачьей среде, с государственной поддержкой программ патриотического воспитания молодежи. В Ханты-Мансийском автономном округе - Югре на сегодняшний день действуют более 110 кадетских классов, в том числе 59 классов с использованием казачьего компонента в образовательной программе [17]. Актуальными задачами становятся предварительное понимание роли казачества на северных территориях, как в прошлые времена, так и в нашу эпоху, а также разработка методических оснований преподавания казачьей истории с учетом её регионального компонента и написание соответствующих требованиям времени учебно-методических пособий.

Целью статьи является определение основных принципов создания такого типа учебного пособия, как хрестоматия. Выбор «жанра» обусловлен акцентированием в стандартах самостоятельной учебно-поисковой работы учащихся, работы, для организации которой и нужны пособия «хрестоматийного» типа ${ }^{1}$. Решить частные вопросы, а правила подготовки учебных пособий именно частными и являются, невозможно без выяснения вопросов общего порядка. Поэтому в нашей статье оценивается и общее положение дел с преподаванием истории в средней школе.

Научная и научно-практическая литератуpa, посвященная проблемам составления сборников учебных материалов, хрестоматий по истории для средней школы практически отсутствует. Самыми общими формулировками ограничиваются и краткие аннотации, предва- ряющие подобные издания. Одним из примеров такого рода является хрестоматия по истории Ханты-Мансийского автономного округа, подготовленная уральскими специалистами и местными краеведами [16]. Составители объясняют, почему они отдали приоритет «многофункциональным» источникам, каждый из которых освещает разные стороны исторической реальности, дают краткие рекомендации учителю, характеризуют научно-справочный аппарат [16, 7-9].

Современных учебных пособий по истории российского казачества пока совсем немного. В 2000 г. Институт Российской истории РАН издал сборник документов по казачьим войскам Азиатской России XVIII - начала XX вв., но это издание адресовано специалистам [18].

Школьникам предназначены «Хрестоматия по истории донского казачества» М.П. Астапенко [34] и учебное пособие «Многоликий мир казачества» Ю.Н. Круглова [22]. Обращает на себя внимание практически полное отсутствие саморефлексии авторов. Чем руководствовались они при отборе материала, что надо иметь в виду читателю при работе с источниками? Эти пробелы существенным образом сказались на качестве этих, безусловно, интересных книг.

В сети Интернет выложены и многочисленные учительские программы элективных курсов: Л.М. Зеель [15], В.Н. Ратушняк, О.В. Ратушняк и М.В. Мирук [28] и многие другие. Выполненные с разной степенью интереса к работе с разным качеством, они ещё раз подтверждают необходимость в издании добротной учебно-методической литературы по казачьей истории. В 2016 г. увидели свет методические материалы по истории российского казачества, подготовленные одним из авторов настоящей публикации [13]. Они нацелены на переход от простого повествования о прошлом казачества к творческому осмыслению его исторической судьбы, носят проблемный характер, требуют критической работы с источником, учитывают альтернативные возможности исторического развития.

Если идей по части составления хрестоматий обнародовано немного, то литература, по-

${ }^{1}$ В свое время хрестоматийную форму организации самостоятельной работы учащихся по истории предлагал один из старейших русских историков-методистов Я.С. Кулжинский. - Кассир, Е.И. Проблема исследовательской деятельности в теории и методике обучения истории / Е.И. Кассир // Историко-педагогические чтения. - 2005. - № 9. - С. 359. 
свящённая вопросам методики преподавания истории, напротив, весьма обширна. Анализ современной российской литературы по методике преподавания истории не входит в наши задачи. Но поскольку эта литература является научным базисом для разработки учебных и методических изданий, нельзя не отметить наиболее интересные её явления. Данная литература призвана облегчить освоение учительством «инновационных» методов работы. Они же, в свою очередь, как общепринято считать, обеспечивают всестороннее развитие личности учащегося. Эта цель и многие «сопроводительные» методические идеи сами по себе «инновационными» не являются. На роль инноваций ${ }^{2}$, как мы полагаем, претендуют два типа работ - статьи по частным методикам, выстроенным на основе позитивного в основном зарубежного опыта и труды теоретические, посвящённые природе и эволюции собственно самой научной дисциплины - методики преподавания истории. К первой категории отнесём методики «позиционного обучения» Н. Е. Вераксы, «шести шляп мышления» Э. Боно, метод Келлера Personal System instruktion, oxaрактеризованные М.Н. Дудиной $[11,45]$, отчасти новые системы усвоения и оценки знаний, представленные в статьях М. В. Волковой [8] и Г.Ю. Зверевой [14, 129-130]. Названные и близкие им работы интересны тем, что сугубо методические штудии уживаются здесь с авторской рефлексией по поводу собственно истории, как науки. Очевидно, что развитие методики преподавания как научной дисциплины дошло до известной черты, за которой к учёным и практикам приходит понимание её полидисциплинарного качества. Характерны рассуждения В.Р. Шаяхметовой: «как проанализировать и представить учащимся всю сложность и многообразие исторического процесса, включающего культурные нормы, ценности, стереотипы как элементы мотивации поведения и деятельности? Как показать учащимся уникальность исторического развития во всей его конкретности и многообразии? Как донести до учащихся нелинейность исторического развития» [39, 489]. Автор подхо- дит к мысли о недостаточности методики преподавания истории для решения названных проблемных вопросов.

Характерна в этом отношении статья A.В. Петрова, прямо формулирующая понимание органического единства методики и истории, фактически - появление новой научной дисциплины - методики истории (а не просто её преподавания) [27, 28-31]. Весьма симтоматично и участие учёных-историков в создании учебной литературы для учащихся средней школы и студенчества [10; 13; 19].

Поэтому считаем уместным привести краткую характеристику историографии казачества. Старая, дореволюционная и современная отечественная литература весьма обширна. Качественные историографические обзоры представлены в трудах наших соотечественников Е.И. Дулимова и В.К. Цечоева [12], М.В. Татарченко [31], И.Ю. Юрченко [40], Б.Н. Недбайло [25], В.Н. Бурдуна [6] и др. Активно занимаются казачьей историей и в сопредельных с Россией странах, связанных с нами общей исторической судьбой, а также в Европе, Канаде и США [1; 23; 36]. Многое делается для изучения казачьей истории на Украине. Результаты усилий украинских исследователей получили своё обобщение как в общеисторических трудах, так и в специальных историографических статьях, посвящённых отдельным вопросам истории российского и украинского казачества. Следует назвать работы С.М. Цигульского [35], Д. В. Колодчука [21], К. С. Гири [7] и др. Не случайно российский специалист И.Ю. Юрченко пишет о современном взрыве интереса к историческому прошлому казачества, указывая, что только в российской литературе за первое десятилетие XXI в. о казаках было издано больше литературы, чем за всю предыдущую историю их изучения XVII-XX вв. [40, 58].

Современная проблематика истории казачества весьма разнообразна: от событийных сюжетов, связанных с участием казаков в военно-политических событиях и процессах [2; 5], темы военной подготовки и военного искусства [9; 38], до исследований в духе новой

\footnotetext{
${ }^{2}$ Инновация вообще является крайне неудачным, этимологически двусмысленным понятием. «Ин-» может играть роль предлога «в», инновация в этом случае предстает как нечто находящееся внутри новации (?) или вообще выступать как отрицательная частица - «не-» новация. В «классическом» смысле это постмодернистское словечко может быть истолковано, как актуальное современное знание, материализованное в некую новую вещь, модель, машину, технологию.
} 
социальной и институциональной истории [1, $4 ; 24 ; 33 ; 37]$, изучения образов и ментальностей $[4 ; 20 ; 29 ; 41]$.

\section{Материалы и методы}

Материалами для настоящей статьи послужили как проанализированные выше, так и иные тексты исторического, историографического и историко-методического характера, обширный корпус документальных, литературных, художественных источников, освещающих историю казачества. Современные исследования, являясь ориентиром в историко-казачьей проблематике, помогают методистам-историкам в поисках адекватных способов исторического познания, в определении тематики и структуры учебных пособий, сборников документов и хрестоматий, а разнообразные источники - служат материалом для составления последних.

Современные способы исторического мышления выражаются, прежде всего, в так называемых «новых историях», нацеленных на изучение социального, культурного, интеллектуального, личностного, шире - культурно-антропологического в историческом процессе [26, 73-111]. В отличие от «старого» «нарративного» подхода к истории, который в средней школе, в преподавании истории вообще-то, необходим, как рассказ об общем, о целом, новации позволяют высвечивать частности, поддерживать живую связь с прошлым. В этом отношении важны и так называемый визуальный поворот, разрабатывающий возможности исторического познания через визуально воспринимаемый источник, и усиление этнографической части контента, апеллирующей к этнической культуре.

Преподавательский опыт показывает, что только через сочетание «старого доброго» нарратива с новыми подходами к истории мы сможем помочь учителю решить те проблемы, которые представлены выше в эмоциональной формулировке В. Р. Шаяхметовой [39, 489]. Заметим, что эти подходы, на наш взгляд, вполне соответствуют логике А. В. Петрова, провозгласившего рождение нового научного направления - методики истории.

\section{Результаты}

Обобщения и выводы, к которым пришли авторы, делятся на три группы: это оценка современного состояния и перспектив российского казачества, ситуации в школе, в преподавании истории, и, наконец, требования к составлению сборников учебных материалов (хрестоматий) по истории казачества.

1. Современное казачество.

Первое, из чего мы, готовясь к введению курса истории российского казачества в школе, должны исходить, это общее понимание исторического контекста, связанного как с прошлым казачества, так и его современным возрождением. Участники образовательного процесса должны ясно представлять ряд важных моментов, характеризующих это прошлое и настоящее и опосредованно представленных в хрестоматийных материалах:

1) Казачество относится к периферийным социумам, существование которых изначально и на протяжении значительного исторического времени определялось условиями пограничья и военной опасности. Сохранение данной исторической памяти до сих пор достаточно актуально на северных окраинных территориях, в том числе и в нашем крае.

2) Во многом эти и иные условия способствовали архаизации социальных отношений, что сближает казачий социум с ориентированными на собственные личные усилия ранними потестарными обществами. Даже XXI в. суровый климат и низкая плотность населения на обширных пространствах Севера, субъективно порождают аллюзии с некогда существовавшим Диким Полем или линией фронтира. Известное высказывание М.М. Сперанского, что Сибирь является страной Дон Кихотов, вполне применимо и современной Югре.

3) Казачья этика предполагала, да и сейчас предполагает, наличие коллективизма, дисциплину, милитаризацию этического и эстетического сознания. Работа в современной нефтегазовой отрасли настоятельно требует самоотверженности, централизации и почти военной дисциплины.

4) У казаков развито чувство собственного достоинства, ориентация на личностный рост, способность самостоятельно принимать решения в критических ситуациях. Не секрет, что издавна на Север мигрировала именно социально активная часть населения, усилиями которой было построено, да и сейчас существует наше Отечество.

5) Эти и ряд других характерных черт ка- 
зачьей культуры привели к тому, что в постсоветской России, в условиях нарастающей атомизации и распада прежних социальных структур, ценности казачества оказались привлекательны для значительного числа граждан современной России, вне зависимости, от того имеют ли нет они казачьи корни. Как известно, в 1880 г. казачьи команды Березова и Сургута юридически были упразднены, с переводом местных казаков в мещанское сословие, что нисколько не препятствует современному возрождению казачества на территории округа.

6) Государственная политика Российской Федерации также стала дополнительным стимулом для возрождения отечественного казачества, хотя здесь и не обошлось без конъюнктурных моментов и острой борьбы за бюджетное финансирование.

7) Внутренняя противоречивость современного казачьего движения не отменяет присутствия множества положительных моментов.

8) По сути, при благоприятных возможностях, казачество с его демократическими началами может стать одним из элементов формирующегося гражданского общества, как в субъектах Федерации, так и в муниципальных образованиях или же, напротив, разрушительной деструктивной силой.

9) Всё вышеизложенное заставляет обращать пристальное внимание на развитие казачьей культуры и процессы её воспроизводства с привлечением исторической конкретики. К сожалению, в данной сфере (на общероссийском уровне, в Сибири и в Югре) имеется ряд нерешённых проблем.

10) В частности, быстро сложился разрыв между тягой к возрождению казачества и дефицитом историко-казачьей литературы, прежде всего, научно-популярной и учебной. Преподаватели истории казачества, особенно выходцы из военной и казачьей среды, сегодня нередко оказываются в затруднительном положении. Они не знают, как подступиться к педагогическому процессу и с чего начать.

2. Состояние школьного исторического образования.

Из перечисленных условий и обстоятельств вытекает один, может не вполне очевидный, вывод. Гражданский долг учительства, всех работников народного образования заключается не в производстве планово-проектно-отчетной бумажной и интерактивной документации, не в выслуживании перед «начальством» и «работе на портфолио», а в просвещении, образовании, социализации учащихся [3]. О воспитании любящего свой край, уважающего свой народ, его историю, культуру и традиции молодого человека говорят и образовательные стандарты [32].

Мы убеждены в том, что главным фактором здесь является личность учителя. Это актуально и для формирования казачьей культуры, в которой традиционно высок авторитет старшего, знающего, опытного, традиционно высоко значение казачьего духа, казачьего братства. Основными средствами обучения поэтому, наряду с организацией самостоятельной работы учащихся, должны оставаться одухотворенное слово, прямой разговор и доверительная беседа, вдумчивое чтение. Задача учителя не только в том, чтобы помочь учащимся найти и сделать «своей» историческую информацию, его основная работа заключается и в раскрытии научной картины прошлого, её поэтики, в воссоздании достоверных образов наших зачастую забытых предков, в донесении до учащихся «аромата» ушедших времен. Без этого занятия историей превращаются в вынужденную отсидку на занятиях, в «факультет ненужных вещей».

3. Требования к составлению хрестоматий по истории казачества.

Результаты историко-методической работы могут быть объективно оценены тогда, когда они воплощены в готовый проект. Требования хороши тогда, когда ты можешь предъявить их, прежде всего, к себе самому. Исходя из вышесказанного, дадим здесь краткую характеристику «Хрестоматии по истории российского казачества», в разработке которой авторы статьи принимали непосредственное участие.

Итак, в Обско-угорском институте прикладных исследований и разработок подготовлена «Хрестоматия по истории российского казачества», предназначенная, прежде всего, для учащихся старших кадетских классов средней школы с казачьим компонентом в образовательной программе. Структура книги построена по проблемно-тематическому принципу в соответствие с ранее изданными вышеупомянутыми методическими материалами [13, 3-4]. В первую её часть включены такие материалы по казачьей истории как: первые свидетельства о казаках, «сибирское взятие», «азовское сидение», народные войны Степана 
Разина и Емельяна Пугачёва. Во второй части размещены тексты о службе и социальноэкономическом быте казачества - линейного и городового - имперской эпохи, а также о казачьей форме, чинах и наградах. Третья посвящена духовной культуре казачества и образам казаков в литературе и искусстве.

Главное, к чему мы стремились при подборе и презентации текстов - сделать их не только объектом изучения и переживания, но и субъектом, участником исторического диалога: учитель - ученик - источник $[13,10]$. Это тексты, по возможности краткие и яркие, способные вызвать эмоциональную реакцию читателя. Среди них и документы той или иной исторической эпохи, и публикации известных в свое время любителей-казаковедов, умевших ярко и образно говорить с казачьей молодежью, с казачатами, и публицистические очерки, и художественно-литературные, и даже живописные произведения.

Во-вторых, отчасти по названным соображениям мы отказались от текстов современных исследователей, пишущих сухо, почти исключительно для специалистов. И хотя отдельные положения классиков русской историографии XIX - начала XX вв. сегодня устарели, мы использовали цитаты Н.И. Костомарова, С.М. Соловьева, В.О. Ключевского и других историков прошлого.

В-третьих, тексты заимствовались нами, если не из академических изданий советской эпохи, то из изданий первых, а применительно к художественной литературе - обычно прижизненных изданий авторов. Отсюда и использование дореволюционной орфографии, по выражению Д.С. Лихачёва, складывавшейся на протяжении веков, а потому органично соответствовавшей «русскому языку и русскому духу».

В-четвертых, эти тексты, взятые из соответствующих изданий, приведены нами практически без изменений орфографии и пунктуации, и, как правило, лишены редакционных примечаний. Это открывает широкие возможности для самостоятельной поисковой, в том числе словарной работы.

Пятое замечание касается территориальных и хронологических рамок «Хрестоматии». Она построена с учетом соотношения общероссийских реалий и регионального компонента. В ряде случаев общее представление о прошлом казачества локализуется привлеченными сибирскими материалами. Это вполне оправданно, если учитывать, что основной контингент читателей данной книги - учащиеся XМАО - Югры. По нашему мнению, именно такой симбиоз будет наиболее действенным при воспитании не показного, подлинного патриотизма. В хрестоматии представлены тексты, показывающие казачество на протяжении его досоветской истории. Советская эпоха, начиная с Гражданской войны, привела к расколу российского казачества, породила массовые репрессии, исход казаков в эмиграцию, участие части этой эмиграции, вставшей на национал-предательские позиции, в фашистском нашествии на СССР. Понятно, что эта эпоха нуждается в основательном научном изучении, нежели в презентации её трагических страниц в книге для школьников.

\section{Обсуждение и заключения}

Требования федеральных образовательных стандартов - это основные направления, по которым должна развиваться современная школа, строиться учебно-воспитательный процесс. Очевидно, что учительство нуждается в творческом освоении требований стандартов. В порядке обсуждения считаем необходимым высказаться по поводу деятельностно-компетентностного подхода.

Воспитание патриотизма - многоаспектный процесс. В школе - это, прежде всего, уроки по гуманитарным предметам - истории, литературе, русскому и родному языку, а в классах с казачьим компонентом - и по казачьей истории. Мы согласны с мнением В.С. Сенашенко о неуместности ориентации на компетенции в гуманитарном знании [30]. Тем более что компетентностный подход на современном учебно-методическом новоязе нередко мыслится как альтернатива «знаниевому». К сожалению, и учитель подчас становится жертвой «диссеминации» «инновационной» педагогики, огульных требований «начальства», моды на бесконечные «проекты», что не способствует спокойной, вдумчивой, ответственной работе. «Современное образование отказывается от традиционного представления результатов обучения в виде знаний (!), умений и навыков учащихся, - читаем в одном из докладов учителей истории на научно-практической конференции, - так как новые образовательные стандарты 
носят деятельностный характер и направлены на развитие личности ребёнка» $[42,63]$. Вот так. Перед нами «инновационно» сделанная «личность», но ... без знаний истории?

Между тем гуманитарные знания - это не «информация» как таковая, это - особенные знания, они усваиваются не только разумом, но и переживаются. Эта особенность их не всегда учитывается в нашей школе. Современные требования к организации учебного процесса и к отчетности, которая часто оказывается важнее работы, к использованию IT и иных «современных технологий» вкупе с ЕГЭ ориентированы как раз на индивида, но не на личность. В то время как в центре образования должна стоять именно личность. Речь идёт и о личности учащегося - в данном случае потенциального казака, будущего активного гражданина страны, о человеке, который уже сейчас способен чувствовать фальшь, способен на самостоятельный поступок. Речь идёт и о личности учителя. Ведь воспитание свободных граждан немыслимо без свободной и ответственной личности учителя. Увы, сегодняшние поветрия таковы, что ему отводятся лишь две роли: а) тьютера, помощника учеников, которые самостоятельно осваивают «универсальные учебные действия», позволяющие добывать «информацию»; б) ЕГЭшного репетитора - натаскивателя, работающего все с той же «информацией». Учитель теперь обязан лишь оказывать образовательные услуги. Собственно воспитательное влияние на учащихся при этом сводится к минимуму. Возникшие педагогические лакуны школьное начальство пытается компенсировать имитационной деятельностью: сочиняются различные «проекты» и проводятся «мероприятия по воспитательной работе». Всё это отдает компанейщиной, которая не способна заменить полноценный труд учеников на уроках, а, следовательно, пробудить их умы и тронуть юные сердца.

Проект представленной здесь «Хрестоматии» получил поддержку активистов казачьих обществ Югры, выраженную на заседании круглого стола «Организация взаимодействия казачьих обществ с исполнительными органами государственной власти и органами местного самоуправления в сфере гражданско-патриотического воспитания молодежи» Межрегионального форума: диалог национальных культур 11 ноября 2017 г.

\section{Список источников и литературы}

1. Witzenrath Ch. Cossacks and the Russian Empire, 1598-1725. Manipulation, Rebellion and Expansion into Siberia. London: Routledge, 2007. 259 p. URL: http://www.twirpx.com/file/1481289/ (дата обращения: 15.11.2017).

2. Агафонов А.И., Трут В.П. Донские казаки в Бородинском сражении (26 августа 1812 г.) // Проблемы национальной стратегии. 2012. № 4. С. 199-214.

3. Афанасьева В. Открытое письмо министру образования РФ Ольге Васильевой. (2. Бумажная паранойя и канцелярская шизофрения). URL: http://muzobozrenie.ru/vera-afanas-eva-otkry-toe-pis-mo-ministruobrazovaniya-rf-ol-ge-vasil-evoj/ (дата обращения: 15.11.2017).

4. Березиков Н.А. Казаки-землепроходцы и аборигены Сибири: первые встречи и рождение образов // Гуманитарные науки в Сибири. 2010. № 3. С. 56-59.

5. Бражников А.А. Казаки-нагайбаки на фронтах первой мировой войны // Вестник Томского государственного университета. История. 2010. № 3. С. 39-45.

6. Бурдун В.Н. Кубанское казачество в войнах второй половины XIX века в освещении дореволюционной отечественной историографии. Монография. Краснодар: Парабеллум, 2013. 169 с.

7. Волкова М.В. Методика полного усвоения знаний в преподавании истории // Альманах современной науки и образования Тамбов: Грамота, 2007. № 7 (7). Ч. II. C. 31-34. URL: www.gramota.net/ materials/1/2007/7-2/11.html (дата обращения: 15.11. 2017).

8. Гіря К.С. Взаємостосунки запорізьких і донських козаків кінця XV - початку XVIII ст.: історіографія проблеми: Автореф. дис... канд. іст. наук. Донецьк, 2007. 19 с.

9. Гузенко Ю. І. Легка козацька кіннота (кінець XVI - перша половина XVII ст.): підготовка і тактика // Науковий вісник Миколаївського національного університету імені В. О. Сухомлинського. 2014. № 3.37. C. 28-32. URL: http://mdu.edu.ua/wp-content/uploads/2015/03/83.pdf (дата обращения: 16.11.2017).

10. Давыденко Н.А., Зверев В.А., Зуев А.С. [и др.] История Сибири: история России через историю регионов: инновационный учебно-методический комплекс «История»: учеб. пособие для образоват. учреждений РФ: модуль 5.1. М.: Интеграция: образование и наука, 2015. 218 с. 
11. Дудина М.Н. Необходимость и возможность перехода от традиционной методики к инновационной в преподавании истории в школе // Историко-педагогические чтения. 2016. Т. 1. С. 39-47.

12. Дулимов Е.И., Цечоев В.К. Славяне средневекового Дона. К вопросу о предпосылках формирования казачьей государственности. Ростов-на-Дону: Ростиздат, 2001. 319 с.

13. Ершов М.Ф. История российского казачества. Методические материалы в помощь учителю истории в старших классах. Ханты-Мансийск: Печатный мир, 2016. 92 с.

14. Зверева Г.Ю. О педагогических технологиях, необходимых к использованию в учебном процессе в условиях перехода на ФГОС ОСО // Актуальные проблемы изучения всеобщей и отечественной истории и методик их преподавания Материалы IV научно-методического семинара студентов, аспирантов и преподавателей кафедр истории России, документоведения и всеобщей истории. Нижневартовск: изд-во Нижневартовского гос. ун-та, 2015. С. 126-131.

15. Зеель Л.М. Программа элективного курса «История казачества»// Info-уроки. URL: https:// www.infouroki.net/programma-elektivnogo-kursa-istoriya-kazachestva-17-chasov.html (дата обращения: 12.10.2017).

16. История Ханты-Мансийского автономного округа с древности до конца ХХ века. Хрестоматия. Екатеринбург: Волот, 1999. 302 с.

17.Кадетскоебратство//Новости Югры. боктября 2016.URL:https://ugra-news.ru/article/06102016/37587 (дата обращения: 12.10.2017).

18. Казачьи войска Азиатской России в XVIII - начале XX века (Астраханское, Оренбургское, Сибирское, Семиреченское, Уральское): сб. док. М.: ИРИ РАН, 2000. 428 с.

19. Кириллов, А.К. История для всех. URL: http://al-kir.ru/history/hist-mass.html (дата обращения: 15.11.2017).

20. Козловська $€$. А. Відображення образу козака у польському мистецтві кінця XIX- початку XX у контексті польсько-українських відносин // Вісник Харківської державної академії дизайну і мистецтв. Мистецтвознавство. Архитектура. 2011. № 4. С. 125-129. URL: http://nbuv.gov.ua/UJRN/had_2011_4_33 (дата обращения: 15.11.2017).

21. Колодчук Д.В. Козаки Нової Січі в обороні запорозьких прав і вольностей: історіографія XX початку XXI ст. // Наукові праці [Чорноморського державного університету імені Петра Могили]. Сер.: Iсторія. 2010. Т. 140, Вип. 127. С. 125-131. URL: http://nbuv.gov.ua/UJRN/Npchdui_2010_140_127_25 (дата обращения: 16.11.2017).

22. Круглов Ю.Н. Многоликий мир казачества. Учебное пособие. Ростов-на-Дону: БАРО-ПРЕСС, 2007. $128 \mathrm{c}$.

23. Кудінов Ю.М. А. Гигорович. Бібліографія козацтва. Вибрана бібліографія запорізьких та інших козаків України, донських козаків Росії і кубанських козаків; «Тої слави козацької повік не забудем...»: Рекоменд. бібліограф. покажчик з історії українського козацтва; Ucraina terra Cosaccorum: Україна - земля козацька: Бібліограф. нарис // Український історичний журнал. 2010. № 5. C. 219-221. URL: http://nbuv. gov.ua/UJRN/UIJ_2010_5_18 (дата обращения: 17.11.2017).

24. Мациевский Г.О. Особенности социально-демографического облика казачества на рубеже ХIX, $\mathrm{XX}$ веков // Научные ведомости Белгородского государственного университета. Серия: История. Политология. 2013. № 1 (144). Вып. 25. С. 97-103. URL: https://cyberleninka.ru/article/n/osobennosti-sotsialnodemograficheskogo-oblika-kazachestva-na-rubezhe-xix-xx-vekov (дата обращения 15.11.2017).

25. Недбайло Б.Н., Соклаков А.Ю., Хасанов Р.Ш., Хаткевич Ю.В. Донское казачество на страже государственности в XIX - первой четверти XX в.: историографический, исторический и правовой аспекты служебной организации. Монография. М.: РИО Военного ун-та, 2011. 261 с.

26. Орлов И.Б. «Человек исторический» в системе гуманитарного знания. М.: Изд. дом Высшей школы экономики, 2012. $191 \mathrm{c.}$

27. Петров А.В. О предмете методики истории // Труды исторического факультета Санкт-Петербургского университета. 2010. № 2. С. 27-34.

28. Ратушняк В. Н., Ратушняк О.В., Мирук М.В. Рабочая программа составлена на основе образовательной программы элективного курса «История казачества России. 10-11 классы» // Образовательный портал Prodlenka. URL: https://www.prodlenka.org/metodicheskie-razrabotki/srednjaja-shkola/geografijakraevedenie/224376-rabochaja-programma-jelektivnogo-kursa-istori.html (дата обращения: 15.11.2017).

29. Рудакова Н.I. Український історичний епос: художня трансформація образу козака // Літературознавчі студії. 2013. Вип. 37 (2). С. 266-272. URL: http://nbuv.gov.ua/UJRN/Lits_2013_37(2)_41 (дата обращения: 16.11.2017).

30. Сенашенко В.С. О компетентностном подходе в высшем образовании // Высшее образование в России. 2009. № 4. С. 18-24. 
31. Татарченко, М.В. Изучение государственно-правовых институтов и права донского казачества XVIXVII вв. в новейшей российской историко-правовой науке (1991-2011 гг.) // Бизнес в законе. 2011. № 4. C. 33-39.

32. Федеральные государственные образовательные стандарты // Российская газета. 21 июня, 1912. URL: https://rg.ru/2012/06/21/obrstandart-dok.html (дата обращения: 26.09.2017).

33. Фігурний Ю. Міграції запорозьких козаків у першій половині XVII-XVIII ст. // Українознавчий альманах. 2012. Вип. 7. С. 195-197. URL: http://nbuv.gov.ua/UJRN/Ukralm_2012_7_62 (дата обращения: 20.11.2017).

34. Хрестоматия по истории донского казачества (с древнейших времен до 1920 года). Ростов-на-Дону: Ростовкнига, 2012. 272 с.

35. Цигульський С.М. Історіографічні аспекти участі малоросійських козаків у війні 1812 р. // Проблеми історії України XIX - початку XX ст. 2013. Вип. 21. С. 280-289. URL: http://nbuv.gov.ua/UJRN/Piu1920_2013_21_30 (дата обращения: 16.11.2017).

36. Чжан С. К вопросу об исследованиях российского казачества в Китае // Вестник Тверского государственного университета. 2014. Сер.: история. № 4. С. 142-154.

37. Шаповал Л. І. Козаки-переселенці з Полтавщини на Кубань: побут та устрій // Чорноморський літопис. 2010. URL: http://nbuv.gov.ua/UJRN/Chl_2010_2_13 (дата обращения: 15.11.2017).

38. Шаталов Д.В. Про типи нападів козаків і татар на українському Степовому Кордоні в другій половині XV - першій половині XVII ст. // Наддніпрянська Україна: історичні процеси, події, постаті. 2011. Вип. 9. С. 23-30. URL: http://nbuv.gov.ua/UJRN/Nuippp_2011_9_5 (дата обращения: 16.11.2017).

39. Шаяхметова В.Р. Методика преподавания истории в контексте современных требований к организации школьного образования // Философия и методология истории. Сб. научн. ст. VI Всероссийской научной конференции. Коломна: изд-во Гос. социально-гуманитарный университет, 2015. С. 488-499.

40. Юрченко И.Ю. Динамика защит и основные направления диссертационных исследований феномена казачества в первое десятилетие XXI века // Историческая и социально-образовательная мысль. 2012. № 3. C. 58-63.

41. Юрченко И.Ю. Казаки: между востоком и западом (фронтирная культура казачества как межкультурный коммуникативный транслятор) // Сборники конференций НИЦ Социосфера. 2011. № 29. С. $187-$ 195.

42. Якунчева М.Г. Современные педагогические технологии как средство реализации требований ФГОС на уроках истории // Роль культурного наследия в современных этнополитических, этнообразовательных, этноконфессиональных процессах. Материалы Всерос. с межд. участием научн.-практ. конф. Саранск: Мордовский гос. пед. ин-т, 2016. С. 62-64.

\section{References}

1. Witzenrath Ch. Cossacks and the Russian Empire, 1598-1725. Manipulation, Rebellion and Expansion into Siberia. London: Routledge, 2007. 259 p. Available at: http://www.twirpx.com/file/1481289/ (accessed 15.11.2017). (In English)

2. Agafonov A.I. Donskie kazaki v Borodinskom srazhenii (26 avgusta 1812 g.) [Don Cossacks in the battle of Borodino (August 26, 1812). Problemy nacional'noj strategii [Problems of national strategy], 2012, no. 4, pp. 199-214. (In Russian)

3. Afanasyeva V. Otkrytoe pis'mo ministru obrazovanija RF Ol'ge Vasil'evoj. (2. Bumazhnaja paranojja $i$ kanceljarskaja shizofrenija) [An open letter to the Minister of education of the Russian Federation Olga Vasilyeva. (2. Paper paranoia and clerical schizophrenia]. Available at: http://muzobozrenie.ru/vera-afanas-eva-otkry-toepis-mo-ministru-obrazovaniya-rf-ol-ge-vasil-evoj/ (accessed November 15, 2017). (In Russian)

4. Berezikov N.A. Kazaki-zemleprohodcy i aborigeny Sibiri: pervye vstrechi i rozhdenie obrazov [Cossacksexplorers and aboriginal of Siberia: the first encounters and the birth of images]. Gumanitarnye nauki v Sibiri [Humanities in Siberia], 2010, no. 3, pp. 56-59. (In Russian)

5. Brazhnikov A.A. Kazaki-nagajbaki na frontah pervoj mirovoj vojny [Cossacks-Nağaybäks on the fronts of the First World Wa]. Vestnik Tomskogo gosudarstvennogo universiteta. Istorija [Bulletin of Tomsk State University. History], 2010, no. 3, pp. 39-45. (In Russian)

6. Burdun V.N. Kubanskoe kazachestvo v vojnah vtoroj poloviny XIX veka v osveshhenii dorevoljucionnoj otechestvennoj istoriografii. Monografija [Kuban Cossacks in the wars of the second half of the XIX century in the light of the pre-revolutionary Russian historiography. Monograph]. Krasnodar: Parabellum Publ., 2013. 169 p. (In Russian) 
7. Volkova M.V. Metodika polnogo usvoenija znanij v prepodavanii istorii [The technique of complete learning in history teaching]. Al'manah sovremennoj nauki i obrazovanija [Almanac of modern science and education], 2007, no. 7(7), Part II, pp. 31-34. Available at: www.gramota.net/materials/1/2007/7-2/11.html (accessed November 15, 2017). (In Russian)

8. Girya K.S. Vzajemostosunky zaporiz'kyh i dons'kyh kozakiv kincja XV - pochatku XVIII st.: istoriografija problem. Donec'k, 2007. 19 p. (In Ukrainian)

9. Guzenko Yu.I. Legka kozac'ka kinnota (kinec' XVI - persha polovyna XVII st.): pidgotovka i taktyka. Naukovyj visnyk Mykolai'vs'kogo nacional'nogo universytetu imeni V. O. Suhomlyns'kogo, 2014, no. 3 (37), pp. 28-32. Available at: http://mdu.edu.ua/wp-content/uploads/2015/03/83.pdf (accessed November 16, 2017). (In Ukrainian)

10. Davydenko N.A., Zverev V.A., Zuev A.S., etc. Istorija Sibiri: istorija Rossii cherez istoriju regionov: innovacionnyj uchebno-metodicheskij kompleks «Istorija»: ucheb. posobie dlja obrazovat. uchrezhdenij RF: modul' 5.1 [History of Siberia: history of Russia through the history of regions: the innovative educational and methodical complex "History": textbook for educational institutions of the Russian Federation: the module 5.1]. Moscow: Integracija: obrazovanie i nauka Publ., 2015. 218 p. (In Russian)

11. Dudina M.N. Neobhodimost' $i$ vozmozhnost' perehoda ot tradicionnoj metodiki $k$ innovacionnoj $v$ prepodavanii istorii $v$ shkole [The necessity and possibility of transition from traditional methods to innovative teaching of history at school]. Istoriko-pedagogicheskie chtenija [Historical-pedagogical readings], 2016, no. 1, pp. 39-47. (In Russian)

12. Dulimov E.I., Tsechoev V.K. Slavjane srednevekovogo Dona. K voprosu o predposylkah formirovanija kazach'ej gosudarstvennosti [The Slavonians of medieval Don. To the question about the prerequisites of formation of the Cossack state]. Rostov-na-Donu: Rostizdat Publ., 2001.319 p. (In Russian)

13. Ershov M.F. Istorija rossijskogo kazachestva. Metodicheskie materialy v pomoshh' uchitelju istorii $v$ starshih klassah [History of the Russian Cossacks. Methodological materials for help to the teacher of history in senior grades]. Khanty-Mansiysk: Pechatnyj mir Publ., 2016. 92 p. (In Russian)

14. Zvereva G.Yu. O pedagogicheskih tehnologijah, neobhodimyh $k$ ispol'zovaniju v uchebnom processe $v$ uslovijah perehoda na FGOS OSO [About educational technologies required for use in educational process in the conditions of transition to the Federal State Educational Standards of General Secondary Education]. Aktual'nye problemy izuchenija vseobshhej $i$ otechestvennoj istorii i metodik ih prepodavanija. Materialy IV nauchnometodicheskogo seminara studentov, aspirantov i prepodavatelej kafedr istorii Rossii, dokumentovedenija $i$ vseobshhej istorii. [Actual problems of studying of world and Russian history and techniques of their teaching. Materials of IV scientific-methodical seminar of students, postgraduates and teachers of chair of history of Russia, the documentation study and world history]. Nizhnevartovsk: Izd-vo Nizhnevartovskogo gos. un-ta Publ., 2015, pp. 126-131. (In Russian)

15. Zeel L.M. Programma jelektivnogo kursa «Istorija kazachestva» [The program of elective course "History of the Cossacks"]. Info-uroki [Info-lessons]. Available at: https://www.infouroki.net/programma-elektivnogokursa-istoriya-kazachestva-17-chasov.html (accessed October 12, 2017). (In Russian)

16. Istorija Hanty-Mansijskogo avtonomnogo okruga s drevnosti do konca XX veka. Hrestomatija [The history of Khanty-Mansiysk Autonomous Okrug from antiquity to the end of XX century. Chrestomathy]. Ekaterinburg: NPMP «Volot» Publ., 1999. 302 p. (In Russian)

17. Kadetskoe bratstvo [Cadet brotherhood]. Novosti Jugry [News of Yugra], 2016, October 6. Available at: https://ugra-news.ru/article/06102016/37587 (accessed October 12, 2017). (In Russian)

18. Kazach'i vojska Aziatskoj Rossii v XVIII - nachale XX veka (Astrahanskoe, Orenburgskoe, Sibirskoe, Semirechenskoe, Ural'skoe): Sb. dok. [Cossack army of Asian Russia in XVIII - early XX centuries (Astrakhan, Orenburg, Siberian, Semirechensk, Ural): coll. of doc.]. Moscow: IRI RAN Publ., 2000. 428 p. (In Russian)

19. Kirillov A.K. Istorija dlja vseh [History for all]. Available at: http://al-kir.ru/history/hist-mass.html (accessed November 15, 2017). (In Russian)

20. Kozlovs'ka Ye.A. Vidobrazhennja obrazu kozaka u pol's'komu mystectvi kincja XIX - pochatku XX u konteksti pol's'ko-ukrai'ns'kyh vidnosyn. Visnyk Harkivs'koi' derzhavnoi' akademii' dyzajnu i mystectv. Mystectvoznavstvo.Arhytektura, 2011,no.4,pp. 125-129.Available at: http://nbuv.gov.ua/UJRN/had_2011_4_33 (accessed November 15, 2017). (In Ukrainian)

21. Kolodchuk D.V. Kozaky Novoi' Sichi v oboroni zaporoz'kyh prav i vol'nostej: istoriografija XX - pochatku XXI st. Naukovi praci [Chornomors'kogo derzhavnogo universytetu imeni Petra Mogyly]. Ser.: Istorija, 2010, Vol. 140, no. 127, pp. 125-131. Available at: http://nbuv.gov.ua/UJRN/Npchdui_2010_140_127_25 (accessed November 16, 2017). (In Ukrainian) 
22. Kruglov Yu.N. Mnogolikij mir kazachestva. Uchebnoe posobie [The multi-faceted world of the Cossacks. Textbook]. Rostov-na-Donu: BARO-PRESS Publ., 2007. 128 p. (In Russian)

23. Kudinov Yu.M. A. Gygorovych. Bibliografija kozactva. Vybrana bibliografija zaporiz'kyh ta inshyh kozakiv Ukrai'ny, dons'kyh kozakiv Rosii' i kubans'kyh kozakiv; «Toi' slavy kozac'koi' povik ne zabudem...»: Rekomend. bibliograf. pokazhchyk z istorii' ukrai'ns'kogo kozactva; Ucraina terra Cosaccorum: Ukrai'na zemlja kozac'ka: Bibliograf. Narys. Ukrai'ns'kyj istorychnyj zhurnal, 2010, no. 5, pp. 219-221. Available at: http://nbuv.gov.ua/UJRN/UIJ_2010_5_18 (accessed November 17, 2017). (In Ukrainian)

24. Matsiyevskiy G.O. Osobennosty socyal'no-demografycheskogo oblyka kazachestva na rubezhe XIX, $X X$ vekov [Features of the socio-demographic appearance of the Cossacks at the turn of XIX, XX centuries]. Nauchnye vedomosty Belgorodskogo gosudarstvennogo unyversyteta. Seryja: Ystoryja. Polytologyja [Bulletin of Belgorod State University. Series: History. Political science], 2013, no. 1 (144), iss. 25, pp. 97-103. Available at: https://cyberleninka.ru/article/n/osobennosti-sotsialno-demograficheskogo-oblika-kazachestva-na-rubezhe-xixxx-vekov (accessed November 15, 2017). (In Russian)

25. Nedbaylo B.N., Soklakov A.Yu., Khasanov R.Sh, Khatkevich Yu.V. Donskoe kazachestvo na strazhe gosudarstvennosti $v$ XIX - pervoj chetverti XX v.: istoriograficheskij, istoricheskij i pravovoj aspekty sluzhebnoj organizacii. Monografija [Don Cossacks on guard of the state in the XIX - first quarter of XX centuries: historiographical, historical and legal aspects of service organization. Monograph]. Moscow: RIO Voennogo unta Publ., 2011. 261 p. (In Russian)

26. Orlov I.B. «Chelovek istoricheskij»v sisteme gumanitarnogo znanija ["The historical person" in the system of humanitarian knowledge]. Moscow: Izd. dom Vysshej shkoly jekonomiki Publ., 2012. 191 p. (In Russian)

27. Petrov A.V. O predmete metodiki istorii [About the subject of methodology of history]. Trudy istoricheskogo fakul 'teta Sankt-Peterburgskogo universiteta [Proceedings of the faculty of history of Saint-Petersburg University], 2010, no. 2, pp. 27-34. (In Russian)

28. Ratushnyak V.N. Rabochaja programma sostavlena na osnove obrazovatel'noj programmy jelektivnogo kursa "Istorija kazachestva Rossii. 10-11 klassy» [The working program based on the educational program of elective course "History of the Cossacks of Russia. 10-11 grades]. Obrazovatel'nyj portal Prodlenka [Educational portal Prodlenka]. Available at: https://www.prodlenka.org/metodicheskie-razrabotki/srednjaja-shkola/ geografija-kraevedenie/224376-rabochaja-programma-jelektivnogo-kursa-istori.html (accessed November 15, 2017). (In Russian)

29. Rudakova N.I. Ukrai'ns'kyj istorychnyj epos: hudozhnja transformacija obrazu kozaka. Literaturoznavchi studii, 2013, no. 37(2), pp. 266-272. Available at: http://nbuv.gov.ua/UJRN/Lits_2013_37(2)_41 (accessed November 16, 2017). (In Ukrainian)

30. Senashenko V.S. O kompetentnostnom podhode $v$ vysshem obrazovanii [About the competence approach in higher education]. Vysshee obrazovanie v Rossii [Higher education in Russia], 2009, no. 4, pp. 18-24. (In Russian)

31. Tatarchenko M.V. Izuchenie gosudarstvenno-pravovyh institutov i prava donskogo kazachestva XVI-XVII $v v$. v novejshej rossijskoj istoriko-pravovoj nauke (1991-2011 gg.) [The study of public-legal institutions and law of the Don Cossacks of XVI-XVII centuries in the modern Russian historical and legal science (1991-2011)]. Biznes v zakone [Business in law], 2011, no. 4, pp. 33-39. (In Russian)

32. Federal'nye gosudarstvennye obrazovatel'nye standarty [Federal state educational standards]. Rossijskaja gazeta [Russian newspaper], June 21, 1912. Available at: https://rg.ru/2012/06/21/obrstandart-dok.html (accessed September 26, 2017). (In Russian)

33. Figurnyj Yu. Migracii' zaporoz'kyh kozakiv u pershij polovyni XVII-XVIII st. Ukrai'noznavchyj al'manah, 2012, no. 7, pp. 195-197. Available at: http://nbuv.gov.ua/UJRN/Ukralm_2012_7_62 (accessed November 16, 2017). (In Ukrainian)

34. Hrestomatija po istorii donskogo kazachestva (s drevnejshih vremen do 1920 goda) [Chrestomathy on history of the Don Cossacks (from the ancient times to 1920)]. Ed. by M.P. Astapenko. Rostov-na-Donu: Rostovkniga Publ., 2012. 272 p. (In Russian)

35. Tsygulskiy S.M. Istoriografichni aspekty uchasti malorosijs'kyh kozakiv u vijni 1812 r. Problemy istorii' Ukrai'ny XIX - pochatku XX st. 2013, no. 21, pp. 280-289. Available at: http://nbuv.gov.ua/UJRN/Piu1920_2013_21_30 (accessed November 16, 2017). (In Ukrainian)

36. Chzhan S. K voprosu ob issledovanijah rossijskogo kazachestva $v$ Kitae [To the question about the research of Russian Cossacks in China]. Vestnik Tverskogo gosudarstvennogo universiteta. Ser: Istorija [Vestnik of Tver State University. Ser.: History], 2014, no. 4, pp. 142-154. (In Russian)

37. Shapoval L.I. Kozaky-pereselenci z Poltavshhyny na Kuban': pobut ta ustrij. Chornomors'kyj litopys. 2010. Available at: http://nbuv.gov.ua/UJRN/Chl_2010_2_13 (accessed November 15, 2017). (In Ukrainian) 
38. Shatalov D.V. Pro typy napadiv kozakiv i tatar na ukrai'ns'komu Stepovomu Kordoni v drugij polovyni XV - pershij polovyni XVII st. Naddniprjans'ka Ukrai'na: istorychni procesy, podii', postati. 2011, no. 9, pp. 23-30. Available at: http://nbuv.gov.ua/UJRN/Nuippp_2011_9_5 (accessed November 16, 2017). (In Ukrainian)

39. Shayakhmetova V.R. Metodika prepodavanija istorii $v$ kontekste sovremennyh trebovanij $k$ organizacii shkol'nogo obrazovanija [Methods of teaching of history in the context of modern requirements to the organization of school education]. Filosofija i metodologija istorii. Sb. nauchn. st. VI Vserossijskoj nauchnoj konferencii [Philosophy and methodology of history. Proceedings of VI all-Russian scientific conference]. Kolomna: Izd-vo Gos. social'no-gumanitarnyj universitet Publ., 2015. pp. 488-499. (In Russian)

40. Yurchenko I.Yu. Dinamika zashhit i osnovnye napravlenija dissertacionnyh issledovanij fenomena kazachestva v pervoe desjatiletie XXI veka [The dynamics of protection and the main directions of dissertation research of the phenomenon of the Cossacks in the first decade of the XXI century]. Istoricheskaja $i$ social'noobrazovatel'naja mysl' [Historical and socio-educational thought], 2012, no. 3, pp. 58-63. (In Russian)

41. Yurchenko I.Yu. Kazaki: mezhdu vostokom i zapadom (frontirnaja kul'tura kazachestva kak mezhkul'turnyj kommunikativnyj transljator) [Cossacks: between East and West (frontery culture of the Cossacks as intercultural communicative translator)]. Sborniki konferencij NIC Sociosfera [Collections of conferences SRC Sociosfera]. 2011, no. 29, pp. 187-195. (In Russian)

42. Yakuncheva M.G. Sovremennye pedagogicheskie tehnologii kak sredstvo realizacii trebovanij FGOS na urokah istorii [Modern educational technology as the means of implementing the requirements of the federal state educational standards on the lessons of history]. Rol' kul'turnogo nasledija v sovremennyh jetnopoliticheskih, jetnoobrazovatel'nyh, jetnokonfessional'nyh processah. Materialy Vseros. s mezhd. uchastiem nauchn.-prakt. konf. [Role of cultural heritage in the modern ethno-political, ethno-educational, ethno-confessional processes. Proceedings of the All-Russian with international participation scientific.-practical conference]. Saransk: Mordovskij gos. ped. in-t Publ., 2016. pp. 62-64. (In Russian)

\section{ИНФОРМАЦИЯ ОБ АВТОРАХ:}

Ершов Михаил Фёдорович, заведующий отделом истории, археологии и этнологии, Бюджетное учреждение ХМАО-Югры «Обско-угорский институт прикладных исследований и разработок» (628011, Российская Федерация, Ханты-Мансийский автономный округ - Югра, г. Ханты-Мансийск, ул. Мира, 14A), кандидат исторических наук.

ORCID 0000-0002-8518-4368

mfershov@mail.ru.

Киселёв Александр Георгиевич, главный научный сотрудник отдела археологии и этнологии, Бюджетное учреждение ХМАО-Югры «Обско-угорский институт прикладных исследований и разработок» (628011, Российская Федерация, Ханты-Мансийский автономный округ - Югра, г. Ханты-Мансийск, ул. Мира, 14А), доктор исторических наук.

ORCID 0000-0003-4677-5250

kiselev1954@mail.ru.

ABOUT THE AUTHORS:

Ershov Mikhail Fedorovich, Head of the Department of History, Archeology and Ethnology, Ob-Ugric Institute of Applied Researches and Development (628011, Russian Federation, Khanty-Mansiysk Autonomous Okrug - Yugra, Khanty-Mansiysk, Mira st., 14A), Candidate of Historical Sciences.

ORCID ID: 0000-0002-8518-4368

mfershov@mail.ru

Kiselev Alexander Georgievich, Chief Scientific Researcher, Ob-Ugric Institute of Applied Researches and Development (628011, Russian Federation, Khanty-Mansiysk Autonomous Okrug - Yugra, Khanty-Mansiysk, Mira st., 14A), Doctor of Historical Sciences.

ORCID ID: 0000-0003-4677-5250

kiselev1954@mail.ru 